\title{
When Will It End? Whether the Right-to-Sue Letter Effectively Limits the EEOC's Investigative Authority
}

\author{
Emily K. Leiker*
}

\section{INTRODUCTION}

In EEOC v. Waffle House, the Supreme Court pronounced the Equal Employment Opportunity Commission (EEOC) "the master of its own case." The EEOC has come a long way since its early days, when many considered the administrative agency a "toothless tiger." 2 In the beginning, "the EEOC was a strange hybrid creature."3 Because the Civil Rights Act of 1964 gave the EEOC very little statutory authority, it was relatively ineffective, and it lacked the power to enforce Title VII of the Act. ${ }^{4}$ The Equal Employment Opportunity Act of 1972, however, amended Title VII to give the EEOC the authority to enforce discrimination claims. ${ }^{5}$ Since the passage of this amendment, the EEOC has exercised its newly-granted authority, which in turn has spurred litigation about the scope of the EEOC's investigative authority. ${ }^{6}$ As a result, courts have been tasked with determining just how much enforcement authority Title VII gives the EEOC. In particular, courts have

\footnotetext{
* J.D. Candidate, 2020, University of Kansas School of Law; B.S., 2017, Fort Hays State University. I would like to thank Professor Lumen Mulligan and the Kansas Law Review editorial staff for all their insight and suggestions throughout the editing process of this Comment. I would also like to thank my family and friends for their love, support, and unfailing confidence in me.

1. 534 U.S. 279, 291 (2002) (holding that the EEOC is not subject to an arbitration agreement between an employer and employee, and that it can still bring suit in its own name to seek victimspecific relief).

2. Michael Z. Green, Proposing A New Paradigm for EEOC Enforcement After 35 Years: Outsourcing Charge Processing by Mandatory Mediation, 105 DICK. L. REV. 305, 352 (2001).

3. Hugh Davis Graham, The Civil Rights ERa: Origins AND DeVElopMENT OF NATIONAL POLICY 1960-1972 157 (1990).

4. See Green, supra note 2, at 320-21 (detailing the legislative history that contributed to the EEOC's lack of enforcement power under Title VII).

5. Congress granted the EEOC greater enforcement authority by allowing it to commence civil actions in the Equal Employment Opportunity Act of 1972, Pub. L. No. 92-261, § 706(f)(1), 86 Stat. 103, 105 (codified as amended at 42 U.S.C. $\$ 2000 \mathrm{e}-5(\mathrm{f})(1)(2012)$ ).

6. See, e.g., EEOC v. Hearst Corp., 103 F.3d 462, 463 (5th Cir. 1997); EEOC v. Union Pac. R.R., 867 F.3d 843, 845 (7th Cir. 2017).
} 
been asked to determine how far the EEOC may stretch its investigatory powers. $^{7}$

Recently, Circuit courts have disagreed about the scope of the EEOC's level of enforcement authority, creating a circuit split among the Fifth, Seventh, and Ninth Circuits. Title VII, which prohibits discrimination on the basis of race, sex, religion, or national origin, ${ }^{8}$ gives the EEOC exclusive authority to investigate workplace discrimination claims once an aggrieved employee files a formal charge. ${ }^{9}$ After an investigation, the EEOC also has the authority to conciliate, litigate, or dismiss these claims for lack of reasonable cause. ${ }^{10}$ Meanwhile, the aggrieved employee cannot bring her own suit in federal court. Instead, she must wait for the EEOC to either (1) sue her employer on her behalf, or (2) issue a right-to-sue letter. ${ }^{11}$ Generally, the EEOC terminates its investigation into a claim once it gives the employee a right-to-sue letter. ${ }^{12}$ On occasion, however, the EEOC continues to investigate a claim even after it issues a right-to-sue letter. ${ }^{13}$ The circuit split concerns whether the issuance of a right-to-sue letter effectively limits the EEOC's authority to continue to investigate a claim.

The circuit split is indicative of a greater issue. Courts are not sure how to determine the scope of the EEOC's authority under Title VII. When analyzing the court decisions in this split in authority, it is unclear how the courts analyze the EEOC's interpretation of its enforcement authority. Each circuit court takes a different approach to decide the issue. While the three circuit courts agree that Title VII authorizes the EEOC to investigate once an aggrieved employee formally submits a claim, they disagree about whether Title VII imposes a limit upon this authority. The Fifth Circuit held that the EEOC's enforcement authority is split into distinct stages, and that a right-to-sue letter effectively prevents the EEOC from continuing the investigation stage. ${ }^{14}$ Conversely, the Seventh and

7. See infra Section II.C.

8. See 42 U.S.C. $§ 2000$-2(a) (2012) ("It shall be an unlawful employment practice for an employer ... to fail or refuse to hire or to discharge any individual, or otherwise to discriminate against any individual with respect to his compensation, terms, conditions, or privileges of employment, because of such individual's race, color, religion, sex, or national origin ....").

9. Id. $\S 2000 \mathrm{e}-5$ (b) (2012 \& Supp. V 2018).

10. Id. $\S 2000 \mathrm{e}-5(\mathrm{~b}),(\mathrm{f})(1)$.

11. Id. $\$ 2000 \mathrm{e}-5(\mathrm{f})(1)$.

12. Filing a Lawsuit, U.S. EQUAL EMP. OPPORTUNITY COMM'N, https://www.eeoc.gov/employees/la wsuit.cfm [https://perma.cc/5HF9-B3ZA] (last visited Oct. 24, 2019) (stating "[the EEOC] will give [the claimant] a Notice of Right to Sue at the time the EEOC closes its investigation").

13. Id.

14. EEOC v. Hearst Corp., 103 F.3d 462, 463 (5th Cir. 1997). 
Ninth Circuits held that Title VII does not limit the investigative authority of the EEOC, and to find otherwise would have unfavorable consequences upon public policy and the effectiveness of the EEOC. ${ }^{15}$ If, however, the courts had applied the same level of deference to the EEOC's interpretation of its investigatory authority, they would have reached the same conclusion. The amount of deference courts afford agency interpretations, if they are to give the agency any level of deference at all, are traditionally determined by the standards set forth in Chevron or Skidmore. If the courts applied Skidmore deference, they likely would have determined the EEOC's interpretation of its investigatory authority was enforceable.

The rest of this Comment proceeds as follows: Part II of this Comment provides the historical background of the EEOC and the Title VII amendments that expanded the scope of the EEOC's enforcement authority, along with a description of the enforcement procedure the EEOC uses in investigating claims. Part II then discusses the circuit split among the Fifth, Seventh, and Ninth Circuits. Part III argues the circuit courts should have applied Skidmore deference to analyze whether the EEOC maintains investigative authority after issuing a right-to-sue letter. Finally, this Comment applies the Skidmore test-examining legislative authority, previous court decisions, and public policy implications - and concludes that the EEOC's interpretation is a valid exercise of its authority. The EEOC has continuing investigative authority over claims, regardless of a right-to-sue letter or the aggrieved employee's civil actions.

\section{BACKGROUND}

The EEOC's enforcement powers have changed drastically since Title VII first created the agency in $1964 .{ }^{16}$ In its early years, the EEOC could not seek judicial remedies for workplace discrimination claims. ${ }^{17}$ In fact, the EEOC's own officials gave it the unfortunate nickname "toothless tiger" because the agency had little authority to enforce Title VII or seek

15. EEOC v. Union Pac. R.R., 867 F.3d 843, 845 (7th Cir. 2017); EEOC v. Fed. Express Corp., 558 F.3d 842, 845 (9th Cir. 2009).

16. See U.S. EQUAL EMP. OPPORTUNITY COMM'N, Pre 1965: Events Leading to the Creation of EEOC, https://www.eeoc.gov/eeoc/history/35th/pre1965/index.html [https://perma.cc/72UH-R5AR] (last visited Oct. 24, 2019) [hereinafter U.S. EQUAL EMP. OPPORTUNITY COMM'N, Creation of EEOC] (providing an overview of the progression of the EEOC's enforcement authority).

17. See Green, supra note 2, at 323 (noting that the EEOC was initially "an agency which merely receives charges, investigates them and attempts to conciliate them"). 
relief for aggrieved employees. ${ }^{18}$ It was not until 1972, when Congress amended Title VII, that the EEOC received the explicit authority it needed to seek relief for employees affected by discrimination in the American workplace. ${ }^{19}$ However, with this new authority came many questions, as employers and courts began to wonder just how much authority Title VII grants the EEOC.

As the EEOC continued to test the strength of its relatively new authority, courts began to disagree on how to determine the scope of the EEOC's authority. With this disagreement came confusion, leading to the circuit split among the Fifth, Seventh, and Ninth Circuits regarding the EEOC's investigative power.

\section{A. Title VII and Its Amendments}

In July 1964, President Lyndon B. Johnson signed the Civil Rights Act of 1964 into law. ${ }^{20}$ Included in the Act was Title VII - a provision that prohibits discrimination in the workplace based upon race, color, religion, national origin, sex, or in retaliation for exercising legal rights. ${ }^{21}$ To enforce Title VII's provisions, Congress formed the EEOC. ${ }^{22}$

The extent of the EEOC's enforcement power was cause for much debate in the early stages of the Civil Rights Act. ${ }^{23}$ While the Education and Labor House Committee proposed broader enforcement authority for the EEOC, the Judiciary Committee advocated for less enforcement authority, only allowing the EEOC to bring a civil suit if conciliation efforts fail. ${ }^{24}$ Ultimately, Congress chose to limit the EEOC's enforcement power. ${ }^{25}$ When Congress first enacted Title VII, the EEOC had the authority to investigate claims but not to file suit or issue cease-and-desist

18. Id. at n.14 (citing Alfred W. Blumrosen, Black EMPloyment AND THE LaW 59 (1971)).

19. See 42 U.S.C. $§ 2000$ e-5(b)-(f)(1) (2012 \& Supp. V 2018) (authorizing the EEOC to conciliate and litigate employment discrimination claims).

20. Jacqueline A. Berrien, Statement on 50th Anniversary of the Civil Rights Act of 1964, U.S. EQUAL EMP. OPPORTUNITY COMM'N (July 2, 2014), https://www.eeoc.gov/eeoc/history/cra50th/index.cfm [https://perma.cc/M36E-9687].

21. 42 U.S.C. $\$ 2000 \mathrm{e}-2$ (a) (2012).

22. See id. §2000e-4; see also Berrien, supra note 20.

23. See Green, supra note 2, at 320-23 (examining the Congressional debate surrounding the EEOC's enforcement power and mechanisms before Title VII's passage).

24. Francis J. Vaas, Title VII: Legislative History, 7 B.C. L. REV. 431, 435-37 (1966) (citing H.R. REP. NO. 88-914, at 2515-16 (1963)).

25. See, e.g., U.S. EQUAL EMP. OPPORTUNITY COMM'N, Creation of EEOC, supra note 16; Green, supra note 2, at 320-23. 
orders. ${ }^{26}$ Title VII only allowed the EEOC "to receive, investigate, and conciliate complaints where it found reasonable cause to believe that discrimination had occurred." 27 Title VII also tasked the EEOC with investigating systemic patterns of discrimination in the workplace. ${ }^{28}$ If the EEOC could not conciliate the complaints, it was to leave the individual employees to bring their own suits. ${ }^{29}$ If the EEOC found evidence of discriminatory patterns, it was to send the issue to the Department of Justice for litigation. ${ }^{30}$

When Congress passed the Civil Rights Act of 1972, it gave the EEOC more enforcement authority. ${ }^{31}$ Congress recognized the EEOC's lack of authority impeded the agency's ability to enforce Title VII, which became a "serious defect" of the statute. ${ }^{32}$ In an attempt to strengthen the EEOC, the amendments to Title VII gave the Commission the power to bring civil suits against private employers if conciliation efforts did not resolve the claim. ${ }^{33}$ The 1972 amendments also allowed the EEOC to bring "pattern or practice" suits against the employer, a power that was originally assigned to the Attorney General. ${ }^{34}$

In addition to its authority under Title VII, the EEOC's authority continued to grow by other means. The Commission was eventually given responsibility in the Age Discrimination in Employment Act of $1967,{ }^{35}$ the

26. See Civil Rights Act of 1964, Pub. L. No. 88-352, § 706(a), (e), 78 Stat. 241, 259-60 (current version at 42 U.S.C. $\$ 2000$ e-5(f) (2012)) (granting investigatory powers in section 706(a), and providing that only the aggrieved party may file suit in section 706(e)).

27. U.S. EQUAL EMP. OPPORTUNITY COMM'N, Creation of EEOC, supra note 16.

28. See 42 U.S.C. $\$ 2000 \mathrm{e}-6$ (a), (c) (2012) (authorizing the U.S. Attorney General to bring pattern or practice suits against public employers, and later authorizing the EEOC to bring pattern-or-practice suits against public and private employers).

29. U.S. EQUAL EMP. OPPORTUNITY COMM’N, Creation of EEOC, supra note 16.

30. Id.

31. See Equal Employment Opportunity Act of 1972, Pub. L. No. 92-261, sec. 2, § 701, sec. 4, § 706, 86 Stat. 103, 103-07 (codified as amended at 42 U.S.C. $\$ \$ 2000 e, 2000 \mathrm{e}-5$ (2012)).

32. Anne Noel Occhialino \& Daniel Vail, Why the EEOC (Still) Matters, 22 HoFSTRA LAB. \& EMP. L.J. 671, 677 (2005) (quoting Harrison A. Williams, Jr., Foreword in S. CoMM. ON LABOR AND Pub. Welfare, 92ND CONG., Legislative History OF THE EQUAL EMPlOyMENT OPPORTUNiTy ACT OF 1972, at III (1972)).

33. 42 U.S.C. $§ 2000 \mathrm{e}-5(\mathrm{f})(1)$ (2012) ("If . . . the Commission has been unable to secure from the respondent a conciliation agreement acceptable to the Commission, the Commission may bring a civil action against any respondent not a government, governmental agency, or political subdivision named in the charge.").

34. Id. $\S 2000 \mathrm{e}-6(\mathrm{e})$.

35. Age Discrimination in Employment Act, Pub. L. No. 90-202, 81 Stat. 602 (1967) (codified at 29 U.S.C. §§ 621-634 (2012 \& Supp. V 2018)) (giving the EEOC investigatory and enforcement powers). 
Rehabilitation Act of $1973,{ }^{36}$ the Americans with Disabilities Act of $1990,{ }^{37}$ and the ADA Amendments Act of $2008 .{ }^{38}$

\section{B. EEOC Procedures}

After the Equal Employment Opportunity Act of 1972 gave the EEOC enforcement authority, the EEOC developed a procedure for enforcing Title VII discrimination claims once they were filed. ${ }^{39}$ The EEOC based its procedure upon Title VII, which laid out important time limits and provisions to ensure an enforcement process that was fair to both employers and employees.

\section{The EEOC's Investigation and Enforcement Process}

First, an aggrieved employee, a person acting on behalf of an employee, or an EEOC member, must file a formal workplace discrimination charge with the agency within 180 days of the alleged discrimination to trigger EEOC enforcement. ${ }^{40}$ After a claim has been filed, the EEOC has ten days to "serve a notice of the charge" of alleged unlawful employment practices on the employer. ${ }^{41}$ The EEOC must then launch an investigation into the claim. ${ }^{42}$ Investigations typically involve the EEOC requesting formal requests for information, conducting on-site visits, obtaining witness information, and taking any statements of position from the employer. ${ }^{43}$

After the investigation, the EEOC decides whether there is

36. Rehabilitation Act, Pub. L. No. 93-112, 87 Stat. 355 (1973) (codified at 29 U.S.C. §§ 791794 (2012 \& Supp. V 2018)) (applying Title VII's enforcement provisions to the Rehabilitation Act).

37. Americans with Disabilities Act, Pub. L. No. 101-336, 104 Stat. 327 (1990) (codified at 42 U.S.C. §§ 12101-12213 (2012 \& Supp. V 2018)) (applying Title VII's enforcement provisions to the ADA).

38. Pub. L. No. 110-325, 122 Stat. 3553 (2008) (codified at 29 U.S.C. § 705 (2012 \& Supp. V 2018) and scattered sections of 42 U.S.C. (2012)) (giving the EEOC power to issue regulations under the Act).

39. See U.S. Equal Emp. OpPoRtunity Comm'N, What You Can Expect After a Charge is Filed, https://www.eeoc.gov/employers/process.cfm [https://perma.cc/FJ8N-YSCR] (last visited Oct. 24, 2019) (providing an in-depth explanation on the procedures the EEOC undertakes after a charge is filed).

40. 42 U.S.C. $\S 2000 \mathrm{e}-5(\mathrm{e})(1)(2012)$.

41. Id. $\S 2000 \mathrm{e}-5$ (b) (providing that the notice to the employer must include "the date, place and circumstances of the alleged unlawful employment practice").

42. Id. (providing that after serving a notice of charge, the EEOC "shall make an investigation thereof").

43. See U.S. Equal Emp. OpPortunity Comm'N, What You Can Expect After a Charge is Filed, supra note 39. 
"reasonable cause" for the claim. ${ }^{44}$ If the EEOC finds there is no reasonable cause, it is to "dismiss the charge and promptly notify the person claiming to be aggrieved and the respondent of its action." 45 If, however, the EEOC finds there is reasonable cause, it begins the enforcement process by utilizing "informal methods of conference, conciliation, and persuasion." 46

Only after conciliation efforts are deemed unsuccessful by the EEOC may it file an action against the employer in civil court, so long as the employer is not a government entity. ${ }^{47}$ While the EEOC's determination that conciliation was unsuccessful is subject to review by a judge, the Supreme Court has held that the "scope of that review is narrow," and that the EEOC has "extensive discretion" to make its own determinations. ${ }^{48}$ Further, the EEOC must wait at least thirty days after the charge was originally filed with the EEOC before it can turn to litigation. ${ }^{49}$ If the EEOC does decide to bring a civil action on behalf of the employee, it generally can seek injunctive and compensatory relief for the employee. ${ }^{50}$ Title VII allows for the aggrieved employee to intervene when the Attorney General acts on behalf of the EEOC "in a case involving a government, governmental agency, or political subdivision."

\section{Issuing the Right-to-Sue Letter}

Filing a claim with the EEOC does not, however, automatically terminate the employee's right to bring her own civil suit. According to Title VII:

If a charge filed with the Commission... is dismissed by the Commission, or if within one hundred and eighty days from the filing of such charge ... the Commission has not filed a civil action under this section... or the Commission has not entered into a conciliation agreement to which the person aggrieved is a party, the Commission . . . shall so notify the person aggrieved and within ninety days after the

44. 42 U.S.C. § 2000e-5(b) (2012 \& Supp. V 2018).

45. $I d$.

46. $I d$.

47. Id. § 2000e-5(f)(1); see also Mach Mining, LLC v. EEOC, 135 S. Ct. 1645, 1649-50 (2015).

48. Mach Mining, 135 S. Ct. at 1649.

49. § 2000e-5(f)(1).

50. Jason A. McNiel, Note, The Implications of EEOC v. Waffle House: Do Settlement and Waiver Agreements Affect the EEOC's Right to Seek and Obtain Victim-Specific Relief?, 38 IND. L. REV. 761, 764 (2005).

51. $\S 2000 \mathrm{e}-5(\mathrm{f})(1)$. 
giving of such notice a civil action may be brought against the respondent named in the charge (A) by the person claiming to be aggrieved or (B) if such charge was filed by a member of the Commission, by any person whom the charge alleges was aggrieved by the alleged unlawful employment practice. ${ }^{52}$

This notice, commonly referred to as the "right-to-sue letter," gives the aggrieved employee the right to bring her own civil suit. Although Title VII specifies a 180-day period before the EEOC can issue a right-tosue letter, the EEOC created a regulation that authorizes it to issue a rightto-sue letter prior to the expiration of 180 days. ${ }^{53}$ Therefore, so long as the employee acts within 30 to 180 days from the time she originally filed her claim with the EEOC, the employee may send the EEOC a right-to-sue letter request. This regulation has been the subject of a circuit split. ${ }^{54}$ While the validity of the EEOC's early right-to-sue letter is outside the scope of this Comment, it is notable that some courts have chosen to uphold the regulation, ${ }^{55}$ showing a trend that courts interpret the EEOC's enforcement powers more broadly. ${ }^{56}$

To understand the EEOC's interpretation of its investigative authority, one can first look to EEOC regulations. 29 C.F.R. § 1601.28(a)(3) establishes that the EEOC does not "terminate the processing of a Commissioner charge" when it issues a right-to-sue letter to an aggrieved employee. ${ }^{57}$ The EEOC Compliance Manual shows the EEOC interprets the phrase "processing of a Commissioner charge" to include investigations. ${ }^{58}$ This regulatory language is consistent with the EEOC's position in the three circuit court cases addressing this issue. ${ }^{59}$

52. $I d$.

53. 29 C.F.R. $\S 1601.28(a)(2)(2018)$.

54. See Robert A. Kearney, Who's "In Charge” at the EEOC?, 50 DrAKE L. REV. 1, 14-20 (2001) (discussing the circuit split and the various court decisions regarding whether the EEOC may issue a right-to-sue letter prior to 180 days).

55. See Walker v. United Parcel Serv., Inc., 240 F.3d 1268, 1274 (10th Cir. 2001) (holding the EEOC's issuance of a right-to-sue letter prior to the expiration of 180 days was a valid exercise of the Commission's authority); Brown v. Puget Sound Elec. Apprenticeship \& Training Tr., 732 F.2d 726, 729 (9th Cir. 1984) (holding the EEOC's early right-to-sue letter was valid). But see Martini v. Fed. Nat'l Mortg. Ass'n, 178 F.3d 1336, 1348 (D.C. Cir. 1999) (holding the EEOC's early right-to-sue letter was invalid).

56. See infra Section III.B.2.

57. 29 C.F.R. $\S 1601.28(\mathrm{a})(3)$ (2018).

58. U.S. EQUAL EMP. OPPORTUNITY COMM'N, EEOC COMPLIANCE MANUAL $§ 6.4$ CONTINUED PROCESSING AFTER NRTS Is ISSUED (2006), 2006 WL 4672976 (using the word "processing" the charge and "investigation" interchangeably).

59. See infra Section II.C. 


\section{The Circuit Split}

Since the 1972 amendments to Title VII, three circuits have addressed whether the EEOC can continue to investigate claims after it issues a rightto-sue letter. Each circuit came to its conclusion using a different analysis. The Fifth Circuit did not take much time to discuss the purpose of the EEOC's enforcement authority or the policy implications, but rather interpreted the language in Title VII in its decision to limit the EEOC's investigatory power. ${ }^{60}$ Conversely, both the Ninth Circuit and the Seventh Circuit concluded that, because Title VII does not prohibit much of the EEOC's investigatory powers, it must allow the EEOC to investigate after the employee files suit. ${ }^{61}$

The following Parts of this Comment examine decisions of the Fifth, Ninth, and Seventh Circuits, identifying the stronger and weaker points of each decision, and how the three circuits came to their conclusions.

\section{The Fifth Circuit}

The first case to tackle this issue was EEOC v. Hearst Corp., where the Fifth Circuit held that the EEOC may not continue an investigation once it gives the aggrieved employee the right-to-sue letter. ${ }^{62}$ In Hearst, two employees filed claims with the EEOC against their employer alleging sexual harassment. ${ }^{63}$ During its investigation, the EEOC issued the employer two subpoenas. ${ }^{64}$ Prior to the conclusion of the EEOC's investigation, the aggrieved employees requested right-to-sue letters, which the EEOC granted. ${ }^{65}$ Two days after the EEOC issued the letters, the employer petitioned to revoke the subpoenas, which the EEOC denied. ${ }^{66}$ The EEOC eventually turned to the district court to enforce the subpoenas, but the employer argued it was not obligated to comply because the EEOC lacked authority to conduct an investigation after issuing a right-to-sue letter. ${ }^{67}$

Although the district court disagreed with the employer's argument

60. EEOC v. Hearst Corp., 103 F.3d 462, 464-67 (5th Cir. 1997).

61. EEOC v. Fed. Express Corp., 558 F.3d 842, 849 (9th Cir. 2009); EEOC v. Union Pac. R.R., 867 F.3d 843, 849 (7th Cir. 2017).

62. Hearst Corp., 103 F.3d at 463.

63. Id.

64. Id.

65. Id.

66. Id. at 464 .

67. Id. 
and ruled in favor of the EEOC ${ }^{68}$ the Fifth Circuit overturned the district court's ruling. ${ }^{69}$ The Fifth Circuit held that once the employee initiates litigation, the EEOC may no longer continue investigating that claim. ${ }^{70}$ In coming to its conclusion, the Fifth Circuit relied upon Title VII and the United States Supreme Court's analysis in Occidental Life Insurance Co. v. EEOC. ${ }^{71}$ The Fifth Circuit identified four stages of the EEOC's Title VII enforcement procedure stemming from Occidental: "filing and notice of charge, investigation, conference and conciliation, and finally, enforcement." 72 The Fifth Circuit stated that once the employee initiates litigation, the EEOC's enforcement stage begins. ${ }^{73}$ The beginning of the enforcement stage therefore ends the investigation stage and the EEOC may no longer continue to investigate. ${ }^{74}$

The Fifth Circuit also briefly examined the legislative history of the 1972 Title VII amendments. The court quoted a Senate Conference Report, which stated that the amendments would enable "the EEOC to process a charge of employment discrimination through the investigation and conciliation stages," ${ }^{, 75}$ and the EEOC only had the authority to seek court involvement "if it has been unable to eliminate an alleged unlawful employment practice by informal methods." $" 76$ The court found that these statements from the report show Congress intended to create the four distinct stages of EEOC enforcement. ${ }^{77}$ Thus, before the EEOC enters the enforcement stage by issuing a right-to-sue letter, Title VII requires that the EEOC must first exhaust the informal methods of investigation and conciliation. The Fifth Circuit believed that allowing the EEOC to issue a

68. Id.

69. Id. at 463 .

70. Id.

71. Id. at 468. The Fifth Circuit is careful to mention that, despite using language from Occidental to make its determination, Occidental was not controlling because the court did "not decide what independent enforcement authority remains with the EEOC now that the private parties have initiated their own enforcement proceedings." Id. at 468-69. The Fifth Circuit thus concluded "only that the time for investigation has passed." Id. at 469. See also Occidental Life Ins. Co. v. EEOC, 432 U.S. 355 (1977); infra Section III.B.2.

72. EEOC v. Hearst Corp., 103 F.3d 462, 468 (5th Cir. 1997).

73. See id. at 469 (concluding "[t]he 'alternative enforcement procedure' identified by the Court in Occidental has begun, and the time for investigation based upon Lamb's and Waddell's charges has passed").

74. Id.

75. Id.

76. Id.

77. Id. ("That Title VII's enforcement structure is deliberately divided into distinct stages is confirmed by the legislative history of the 1972 amendments, which first invested the EEOC with its broad enforcement authority."). 
right-to-sue letter prior to the termination of the investigation would blur the lines between the separate stages and frustrate the purpose of Title VII. ${ }^{78}$

The Fifth Circuit based its decision upon a plain language interpretation of Title VII. ${ }^{79}$ It did not venture to address the EEOC's interpretation of the statute. Additionally, the court did not further explain how or why it determined that each of the four stages of EEOC enforcement must exist separately, aside from noting that Title VII allows the EEOC to file suit after deciding it is unable to use informal methods. However, relying solely upon a plain language interpretation is a mistake because the text of Title VII is ambiguous. ${ }^{80}$ This weakness within the Fifth Circuit's holding led both the Seventh and Ninth Circuits to reject the Fifth Circuit's interpretation.

\section{The Ninth Circuit}

In EEOC v. Federal Express Corp., the Ninth Circuit held the EEOC may continue to investigate a claim even after the complaining employee initiates litigation or joins a class action. ${ }^{81}$ In Federal Express, an African American FedEx employee filed a race discrimination claim with the EEOC. ${ }^{82}$ Because the employee wanted to join a class action suit that had already been filed, the employee requested a right-to-sue letter. ${ }^{83}$ The EEOC granted the employee the letter but informed him that the EEOC "would continue to process [the employee]'s charge." 84 The EEOC then issued a subpoena relating to the charge. ${ }^{85}$ When FedEx would not fulfill the subpoena request, the EEOC sought to enforce the subpoena and filed an action in district court. ${ }^{86}$ The district court granted the EEOC's application to enforce the subpoena, noting that " $[\mathrm{t}]$ he breadth of power granted the EEOC to investigate discrimination charges is such that

78. See id. at 469 ("Congress granted the EEOC broad investigatory authority so that the agency promptly and effectively could determine whether Title VII had been violated, and to assist the agency in its efforts to resolve disputes without formal litigation. These purposes are no longer served once formal litigation is commenced.").

79. Id. at 468 .

80. See infra Section III.B.1.b.

81. 558 F.3d 842, 845 (9th Cir. 2009).

82. Id.

83. Id.

84. Id.

85. Id. at $845-46$.

86. Id. at 846 . 
validity of an administrative subpoena is not weakened unless the EEOC 'plainly lack[s]' jurisdiction." ${ }^{\text {87 }}$

On appeal, the Ninth Circuit considered two relevant questions to determine whether a court may enforce an agency's administrative subpoena: "(1) whether Congress has granted the authority to investigate; [and] (2) whether procedural requirements have been followed." 88 To the first question, the Ninth Circuit noted that courts have a "strictly limited role" in determining an agency's jurisdictional authority, and one should only question this authority if jurisdiction is "plainly lacking." 89 Because the Ninth Circuit found "at least a plausible basis for jurisdiction," this part of the two-part test was met. ${ }^{90}$ To the second question, the Ninth Circuit examined the enforcement procedure provided in Title VII ${ }^{91}$ and emphasized that the EEOC must investigate once a claim has been filed according to Title VII. ${ }^{92}$ Because Title VII requires the EEOC to investigate, the court determined that Congress intended to give the EEOC broad investigatory powers. The court also noted that 29 C.F.R. $\S$ 1601.28(a)(3) is consistent with the EEOC's actions in the case. ${ }^{93}$ Therefore, the Ninth Circuit held that the procedural requirement to investigate a filed claim was met. ${ }^{94}$

The Ninth Circuit concluded by explicitly rejecting the Fifth Circuit's Hearst decision on four separate grounds. ${ }^{95}$ First, the court found that the Fifth Circuit erroneously stated that each stage of the EEOC's investigatory authority is "distinct" because "the beginning of another stage does not necessarily terminate the preceding stage, and Title VII confers upon the EEOC investigatory authority during each stage." 96 Second, the Ninth Circuit explained that the Fifth Circuit's decision implies the charging party's actions control the EEOC's authority. ${ }^{97}$

87. Id.

88. Id. at 848 (9th Cir. 2009) (quoting its previous decision in EEOC v. Karuk Tribe Hous. Auth., 260 F.3d 1071, 1076 (9th Cir. 2001)).

89. Id. (quoting EEOC v. Children's Hosp. Med. Ctr., 719 F.2d 1426, 1430 (9th Cir. 1983)).

90. Id. at $848-49$.

91. Id. at 849-50 (citing 42 U.S.C. $§ 2000 \mathrm{e}-5$ (b) (2012)).

92. Id. at 849 (quoting Occidental Life Ins. Co. v. EEOC, 432 U.S. 355, 359 (1977)).

93. See id. at 850 (holding that the EEOC's actions were consistent with 29 C.F.R. § 1601.28(a)(3) because the EEOC issued the employee a right-to-sue letter upon his request and continued to investigate the employer when it believed the employer had a pattern of violating Title VII).

94. Id.

95. Id. at 851-54.

96. Id. at 851-52.

97. Id. at 852 . 
Instead, the Ninth Circuit contended Title VII makes the EEOC, not the charging party, in control of the charge. ${ }^{98}$ Third, the Ninth Circuit attacked the Fifth Circuit's assertion that Title VII's purposes are complete once the charging party has filed suit. ${ }^{99}$ This, according to the Ninth Circuit, was an incorrect interpretation of the EEOC's purpose. ${ }^{100}$ The Ninth Circuit explained that "the EEOC's investigatory authority serves a greater purpose than just investigating a charge on behalf of an individual."101 Finally, the Ninth Circuit insisted there is no provision within Title VII that would restrict the EEOC's investigative authority once the charging party has filed suit. ${ }^{102}$

The Ninth Circuit oversimplified the issue. It asked whether the EEOC fulfilled its required procedures under Title VII when the agency investigated the claim, but whether the EEOC may continue to investigate a claim after it issues a right-to-sue letter is more a question of the EEOC's investigative limits. The Ninth Circuit examined Title VII's text to ensure the EEOC followed its procedural guidelines, but it did not attempt to interpret whether Title VII places limits upon the EEOC's investigative authority. The Ninth Circuit's failure to address the legislative history of Title VII or to analyze the Supreme Court precedent on the EEOC's enforcement authority results in gaps in its analysis.

\section{The Seventh Circuit}

In EEOC v. Union Pacific Railroad Co., the most recent case to address whether the EEOC maintains investigative authority after the issuance of a right-to-sue letter, the Seventh Circuit sided with the Ninth Circuit, deepening the circuit split. ${ }^{103}$ But the Seventh Circuit went further than the Ninth Circuit, finding that the EEOC may continue to investigate a claim even after a final and valid judgment is entered against an employee. ${ }^{104}$ In this case, two Union Pacific employees filed racial discrimination charges with the EEOC. ${ }^{105}$ The EEOC eventually granted the employees right-to-sue letters upon the employees' request. ${ }^{106}$ The

\footnotetext{
98. Id. (citing EEOC v. Waffle House, Inc., 534 U.S. 279, 291 (2002)).

99. Id. at $852-53$.

100. $I d$.

101. Id. at 852 .

102. Id. at 853 .

103. EEOC v. Union Pac. R.R., 867 F.3d 843, 845 (7th Cir. 2017)

104. Id. at 851 .

105. Id. at 845-46.

106. Id. at 846 .
} 
employees then filed suit against Union Pacific, but the district court granted Union Pacific's motion for summary judgment and dismissed the claims with prejudice. ${ }^{107}$ During this time, the EEOC was continuing its investigation into the claim and issued a second subpoena to Union Pacific. ${ }^{108}$ Union Pacific refused to comply with the subpoenas. ${ }^{109}$ The EEOC then turned to the district court for enforcement, which was granted. ${ }^{110}$

In affirming the district court, the Seventh Circuit applied an abuse of discretion standard to review the enforcement of the subpoenas ${ }^{111}$ - a standard appellate courts often use to review lower court determinations. ${ }^{112}$ In its analysis, the Seventh Circuit first looked to Title VII's text. The Seventh Circuit, like the Ninth Circuit, reasoned that "while a valid charge is a requirement for beginning an EEOC investigation, nothing in Title VII supports a ruling that the EEOC's authority is then limited by the actions of the charging individual." 113 The Seventh Circuit also pointed out that the EEOC is separate from the employee and does not act solely on the employee's behalf. ${ }^{114}$ Therefore, the employee cannot control the actions of the EEOC. ${ }^{115}$ The court stated that allowing employee actions to control the EEOC would undermine the purpose of the EEOC's investigative authority and render it as "merely derivative" of the aggrieved employee. ${ }^{116}$ The public policy implications of such a finding, the court insisted, are "disturbing" and would result in the EEOC representing the general public in fewer claims. ${ }^{117}$

While the Seventh Circuit analyzed Title VII and its legislative history in greater depth than the Ninth Circuit, it too failed to address the more ambiguous provisions of Title VII, such as whether the statute provides any limits on the EEOC's authority. Because each side of the circuit split applied different analyses to reach its conclusions, one is left with the question: how should the limits of the EEOC's investigative authority be

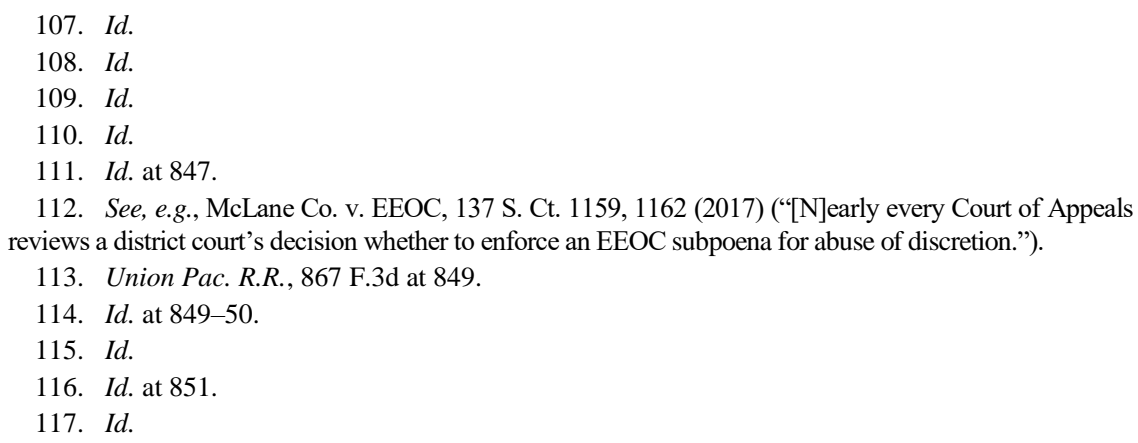


determined?

III. ANALYSIS

One issue has become clear from this circuit split: the courts are uncertain how to determine the extent of the EEOC's investigatory power. The courts should have addressed the issue of deference. There is some debate regarding which level of deference the EEOC's interpretations are entitled. ${ }^{118}$ This Comment argues the deference standard articulated in Skidmore v. Swift \& Co. ${ }^{119}$ is most appropriate. If the Fifth, Seventh, and Ninth Circuits had applied Skidmore deference, they likely would have come to a more unified conclusion regarding whether a post-right-to-sue letter investigation is an appropriate demonstration of the EEOC's Title VII enforcement power.

\section{A. Determining the Appropriate Deference Test}

Generally, when analyzing an administrative agency's authority, courts begin by addressing how the agency interprets its own statutory authority. ${ }^{120}$ Courts then determine the level of deference the interpretation should be afforded. ${ }^{121}$ The two most commonly applied levels of deference are the Chevron ${ }^{122}$ and the Skidmore ${ }^{123}$ tests. Chevron is the standard that affords an administrative agency the highest degree of deference. ${ }^{124}$ If a court determines a statutory provision is "ambiguous,"

118. See, e.g., Eric E. Petry, Comment, Master of Its Own Case: EEOC Investigations After Issuing a Right-to-Sue Notice, 85 U. CHI. L. REV. 1227 (2018) (arguing the EEOC's 29 CFR § 1601.28(a)(3) is entitled to Chevron deference); Jamie A. Yavelberg, Note, The Revival of Skidmore v. Swift: Judicial Deference to Agency Interpretations After EEOC v. Aramco., 42 DuKE L.J. 166, 202 (1992) (arguing Skidmore is the appropriate deference level for judicial review of interpretive rules); see also Theodore W. Wern, Note, Judicial Deference to EEOC Interpretations of the Civil Rights Act, the ADA, and the ADEA: Is the EEOC a Second Class Agency?, 60 OHIO ST. L.J. 1533, 1552-56 (1999) (pointing out that courts used to afford the EEOC "great deference" when considering Title VII issues, but have applied deference less consistently in recent years).

119. 323 U.S. 134 (1944).

120. David Zaring, Reasonable Agencies, 96 VA. L. REv. 135, 144 (2010) (“[Deference] tests apply depending on the source of law that the agency uses to justify the action being disputed in court.").

121. Id. at 143-44 ("Agency interpretations of law are, if reviewable at all, reviewable under one of three basic standards: the deferential Chevron standard, the less deferential Skidmore standardwhich applies when the test set forth in United States v. Mead is met-and the no-deference-at-all standard of de novo review.").

122. Id. at 144-45.

123. Id. at 146 .

124. Id. at 143-45. 
Chevron requires the court to defer to the agency interpretation as long as it is "based on a permissible construction of the statute." 125 Skidmore, on the other hand, affords the agency less deference. ${ }^{126}$ Skidmore only requires a court to uphold an agency interpretation if the agency can persuade the court of the validity of its interpretation. ${ }^{127}$ Whether a court applies Chevron or Skidmore depends on what interpretive authority the governing statute gives the agency. ${ }^{128}$ If a court determines Congress intended the governing statute to grant an agency the authority to make laws based upon interpretations of the statutes, the court gives the agency Chevron deference. ${ }^{129}$ Otherwise, the agency receives Skidmore deference. ${ }^{130}$

Here, because the EEOC is attempting to enforce its own interpretation of its authority under Title VII, some sort of deference test is appropriate. ${ }^{131}$ Interestingly, the Fifth, Seventh, and Ninth Circuits all failed to address deference in their analyses. ${ }^{132}$ Perhaps this is because of the Supreme Court's reluctance to apply deference tests to EEOC questions. In the early years of the EEOC, the Supreme Court seemed to apply a more Chevron-like standard, holding the EEOC's interpretations of Title VII were entitled to "great deference." 133 This changed, however, after the Court decided General Electric Co. v. Gilbert. ${ }^{134}$ Quoting Skidmore, the Court applied a far less deferential standard to analyze an EEOC interpretative guideline. ${ }^{135}$ Since Gilbert, courts have struggled to

125. Id. at 144 (quoting Chevron, U.S.A., Inc. v. Nat. Res. Def. Council, Inc., 467 U.S. 837, 843 (1984)).

126. Id.

127. Id. at 146; see also infra Section III.A.2.

128. William N. Eskridge, Jr. \& Lauren E. Baer, The Continuum of Deference: Supreme Court Treatment of Agency Statutory Interpretations from Chevron to Hamdan, 96 GEO. L.J. 1083, 1097-99 (2008).

129. Id. at 1109. This rule is known as "Step Zero" of the Chevron deference test and it must be satisfied before conducting further analysis under Chevron. See VAlERIE C. BRANNON \& JARED P. Cole, Cong. Research Serv., R44954, Chevron Deference: A Primer 4 (2017), https://fas.org/sgp/crs/misc/R44954.pdf [https://perma.cc/7ZN3-D8N7].

130. Eskridge \& Baer, supra note 128, at 1109 ("[W]hen Congress has not delegated lawmaking authority to the agency, Skidmore deference governs.").

131. See United States v. Mead Corp., 533 U.S. 218, 226-28 (2001).

132. The Seventh Circuit did mention Chevron in a footnote. However, it merely acknowledged that Union Pacific had "challenge[d] whether [\$ 1601.28(a)(3)] is entitled to Chevron deference based on its contrary construction of Title VII." EEOC v. Union Pac. R.R., 867 F.3d 843, 850 n.5 (7th Cir. 2017). The court dismissed this argument and did not address Chevron again.

133. Griggs v. Duke Power Co., 401 U.S. 424, 433-34 (1971).

134. 429 U.S. 125, 140-41 (1976); see also John S. Moot, An Analysis of Judicial Deference to EEOC Interpretative Guidelines, 1 ADMIN. L.J. 213, 222-32 (1987).

135. Gilbert, 429 U.S. at 141-43. 
determine how much deference to give the EEOC's Title VII interpretations. ${ }^{136}$

There is some speculation about why the Court has been reluctant to apply a level of deference to EEOC regulations. One author suggests the lack of deference could be because of the EEOC's historical lack of enforcement powers, its non-technical and relatively uncomplex area of expertise, and the need for Congress to be in charge of delicate policy issues such as those handled by the EEOC. ${ }^{137}$ Regardless of its reasoning, the Supreme Court's reluctance to specify the level of deference to afford the EEOC has left lower courts without guidance. For this reason, courts may choose to follow the Supreme Court and not specify any level of deference at all. However, as this circuit split demonstrates, the courts' inconsistent analyses lead to further confusion and unsettled law. Despite the apparent reluctance, the EEOC's interpretation of Title VII is entitled to some level of deference.

\section{Chevron is Not the Appropriate Analysis}

One solution to this issue is to apply the Chevron test to determine the validity of the EEOC's interpretation of its authority to continue to investigate a claim after issuing a right-to-sue letter. ${ }^{138}$ Chevron allows courts to have a greater regard for a federal agency's interpretation of the law by asking only whether the interpretation was reasonable. ${ }^{139}$ In recent years, Chevron has become a controversial topic, as conservatives argue it gives too much power to the government via administrative agencies. ${ }^{140}$ Even some Supreme Court Justices have become skeptical of Chevron. ${ }^{141}$

136. See infra Section III.A.1.

137. Wern, supra note 118 , at $1578-80$.

138. 29 C.F.R. $§ 1601.28(a)(4)$ (2018) (stating that " $[\mathrm{t}]$ he issuance of a notice of right to sue does not preclude the Commission from offering such assistance to a person issued such notice as the Commission deems necessary or appropriate").

139. Chevron, U.S.A., Inc. v. Nat. Res. Def. Council, Inc., 467 U.S. 837, 844 (1984).

140. Michael Phillis, Justices Won't Hear Chevron Test Over FWS Otter Program, LAW360 (Oct. 29, 2018, 9:54 PM), https://www.law360.com/articles/1096502 [https://perma.cc/ZW3F-VMFK].

141. See Brett M. Kavanaugh, Fixing Statutory Interpretation Judging Statutes, 129 HARV. L. REV. 2118, 2118 (2016) (reviewing RoBERT A. KATZMANN, JUdGING STATUTES (2014), and noting that thenJudge Kavanaugh considers aspects of statutory interpretation methods, including Chevron, to be “troubling”); Randolph J. May, Judge Kavanaugh and the 'Chevron Deference,' WASH. TiMES (July 12, 2018), https://www.washingtontimes.com/news/2018/jul/12/judge-kavanaugh-and-the-chevron-deference/ [https://perma.cc/WSC6-77ES] ("Chief Justice John Roberts, and Justices Clarence Thomas and Neil Gorsuch are in the camp of Chevron skeptics.”); Arthur G. Sapper \& Gwendolyn K. Nightengale, Supreme Court Places Another Limitation on Chevron Deference, NAT'L L. REV. (May 31, 2019), https://www.natlawreview.com/article/supreme-court-places-another-limitation-chevron-deference 
The Supreme Court has been increasingly reluctant to apply Chevron deference to EEOC cases - particularly cases evaluating the EEOC's interpretation of Title VII. ${ }^{142}$ In fact, the Supreme Court rarely invokes Chevron deference in cases involving the EEOC's interpretation of Title VII. ${ }^{143}$ This is largely because "the EEOC was not given rulemaking authority to interpret the substantive provisions of Title VII." ${ }^{144}$ In an attempt to provide guidance in this area, the EEOC published a document titled What You Should Know about EEOC Regulations, Subregulatory Guidance and other Resource Documents. ${ }^{145}$ In the document, the EEOC explains that Chevron's "reasonableness" test only applies to the agency's interpretation of Title VII in "procedural, reporting, and record keeping matters." 146 Simply put, courts will only apply Chevron to the EEOC's procedural matters. The EEOC further states that courts will analyze the EEOC's "interpretive regulations" by electing to allow the interpretations only if "they find EEOC's positions to be persuasive." 147 In other words, "interpretive regulations" are entitled to the less-deferential Skidmore test.

It is not entirely clear whether the EEOC's interpretation of its investigative authority under Title VII is a "procedural matter" or an "interpretive regulation." The Administrative Procedure Act (APA) lends only a small amount of guidance, and most courts take language from the APA to define procedural rules as "rules of agency organization, procedure, or practice." 148 Courts have also gone beyond the language of the ADA to establish what agency rules they consider to be "procedural."

[https://perma.cc/9ZP4-KGXQ] ("On May 28, 2019, the Court in Smith v. Berryhill carved another exception into what has lately proven to be its least-favored precedent."); Pereira v. Sessions, 138 S. Ct. 2105, 2121 (2018) (Kennedy, J., concurring) ("[I]t seems necessary and appropriate to reconsider ... the premises that underlie Chevron and how courts have implemented that decision.").

142. James J. Brudney, Chevron and Skidmore in the Workplace: Unhappy Together, 83 FORDHAM L. REV. 497, 507-08 (2014).

143. Id. (stating that "since 1984, the Court has never relied on Chevron when reviewing EEOC interpretations of Title VII text"). But see Petry, supra note 118, at 1253-54 (2018) (explaining that "the Court has shown willingness to defer to the EEOC's procedural regulations").

144. Edelman v. Lynchburg Coll., 535 U.S. 106, 122 (2002) (O’Connor, J., concurring) (citing EEOC v. Arabian Am. Oil Co., 499 U.S. 244, 257 (1991)).

145. What You Should Know about EEOC Regulations, Subregulatory Guidance and other Resource Documents, U.S. EQUAL EMP. OPPORTUNITY COMM'N, https://www.eeoc.gov/eeoc/newsroom/wysk/ regulations_guidance_resources.cfm [https://perma.cc/2DCE-RV2H] (last visited Oct. 24, 2019) [hereinafter What You Should Know].

146. Id. While the document does not explicitly reference Chevron, it details the deference courts practice in the EEOC's issuance of their own regulations. See id.

147. Id.

148. 5 U.S.C. § 553(b)(3)(A) (2012). See, e.g., Chrysler Corp. v. Brown, 441 U.S. 281, 313-16 (1979); Batterton v. Marshall, 648 F.2d 694, 700-01 (D.C. Cir. 1980); Taylor v. Sec'y of Health \& Human Servs., No. 90-5675, 1991 WL 1104 at*1 (6th Cir. Jan. 8, 1991) (unpublished). 
In a D.C. Circuit decision, the court stated that an agency's procedural rulemaking "should not be deemed to include any action which goes beyond formality and substantially affects the rights of those over whom the agency exercises authority." 149 While arguably a formal procedural issue, the EEOC's authority from 29 C.F.R. $§ 1601.28$ is likely beyond mere formality of the EEOC's procedure. The enforcement authority the EEOC gives itself under the regulation could substantially affect the rights of employers and employees. ${ }^{150}$ Further, the EEOC's authority to continue investigations does not simply dictate how the EEOC must act but also creates obligations for employers and employees. For example, if the EEOC subpoenas an employer, the employer is expected to comply. This interpretation of authority would decide how long the employer must expect EEOC interference, potentially affecting the employers' policies and practices. Many employers likely oppose the EEOC's interpretation of its own authority because of the extra burden it could place upon the workplace. The EEOC's interpretation of the extent of its investigatory authority is therefore probably more within the "interpretive regulation" realm than a mere "procedural matter."

One author, Eric Petry, argues the courts should have applied Chevron deference and that the EEOC's interpretation of its investigatory authority is more likely a procedural interpretation of Title VII. ${ }^{151}$ Petry supported his argument by looking to the Supreme Court, noting the question of whether the EEOC may continue its investigation after issuing a right-tosue letter is similar to the Supreme Court's analyses of two EEOC interpretations in EEOC v. Commercial Office Products Co. and Edelman v. Lynchburg College. ${ }^{152}$ Petry reasons that because the Court implicitly used Chevron in Commercial Office and Edelman to determine similar issues, these issues are probably procedural matters and Chevron is appropriate. ${ }^{153}$

This argument, however, is flawed. In Commercial Office, the Court purported to use a "reasonableness" standard to support the EEOC's regulation that a state agency's proceedings are terminated when it waives its initial processing period. ${ }^{154}$ While Petry argues this analysis is

\footnotetext{
149. Pickus v. U.S. Bd. of Parole, 507 F.2d 1107, 1113 (D.C. Cir. 1974).

150. See infra Section III.B.3.

151. Petry, supra note 118 , at $1258-59$.

152. Id. at 1253.

153. Id. at 1257.

154. EEOC v. Commercial Office Prods. Co., 486 U.S. 107, 115 (1988).
} 
consistent with the deference standard Chevron offers, ${ }^{155}$ the Commercial Office Court did not stop once it determined the regulation was reasonable. Instead, the Court continued and analyzed whether there were any alternative interpretations the EEOC could have made. ${ }^{156}$ The Court concluded that the EEOC's interpretation was the only one possible and that alternatives, such as those suggested by the respondent, would be "absurd."157 As Justice O'Connor pointed out in her concurring opinion, by making these additional determinations, the Court applied a more intensive analysis rather than a mere "reasonableness" test as required by Chevron. ${ }^{158}$

The Court's decision in Edelman is equally unpersuasive. Petry argues the Edelman Court used a Chevron-like test to determine whether an EEOC regulation permits a complainant to verify an EEOC charge after the deadline to file passes. ${ }^{159}$ As Petry acknowledges in his article, however, Edelman explicitly stated it would not address the issue of deference. ${ }^{160}$ In fact, it held that although the EEOC's regulation was reasonable, even without applying the deference test, upholding the EEOC regulation was "the position we would adopt even if there were no formal rule and we were interpreting the statute from scratch." 161 Petry argues the Court implicitly afforded Chevron deference to the EEOC, while the Court, in fact, explicitly declined to apply any sort of deference to the EEOC regulation at all, treating the issue as more of a statutory analysis case than an administrative authority case. ${ }^{162}$

It appears the Court was uncomfortable giving the EEOC strong deference required by Chevron to determine the validity of EEOC enforcement power interpretations in Commercial Office and Edelman. This seems to suggest that these issues are more interpretive regulations than mere procedural matters. Chevron deference is thus probably inappropriate. Applying a simple reasonableness test to determine the validity of the EEOC's interpretation would give too much deference to

155. Petry, supra note 118 , at 1258 .

156. Commercial Office, 486 U.S. at 115-20.

157. Id. at 120 .

158. See id. at 125 (O’Connor, J., concurring) ("But while I agree with much of what the majority says . . . in indicating that the agency's construction is reasonable, in my view the majority goes too far by suggesting that the agency's position is the only one permissible.").

159. Petry, supra note 118, at 1253-54.

160. See id. at 1254; Edelman v. Lynchburg Coll., 535 U.S. 106, 114 (2002) ("But there is no need to resolve any question of deference here.").

161. Id. ("Because we so clearly agree with the EEOC, there is no occasion to defer and no point in asking what kind of deference, or how much.").

162. Petry, supra note 118, at 1254; see also Edelman, 535 U.S. at 114. 
the EEOC as it determines its own enforcement power.

Given the Supreme Court's treatment of similar issues-like in Commercial Office and Edelman - and the strong effect the EEOC's interpretation of its investigative authority would have upon the workplace, it is probably an interpretive regulation rather than a procedural matter. Further, the Supreme Court has historically been reluctant to apply Chevron to EEOC Title VII interpretations. Even the validity of the Chevron test has been called into question. For these reasons, Chevron is probably not the appropriate analysis to apply to this issue.

\section{The Skidmore Test is a More Appropriate Analysis}

The Supreme Court occasionally applies the less deferential Skidmore test when analyzing the EEOC's Title VII interpretations. ${ }^{163}$ Skidmore is appropriate where "statutory circumstances indicate no intent to delegate general authority to make rules with force of law, or where such authority was not invoked." 164 Further, because 29 C.F.R. $§ 1601.28$ (a)(3) is likely an interpretive regulation, the EEOC's interpretation is entitled to deference so long as it is persuasive. ${ }^{165}$

The Skidmore test does not provide much guidance to courts, as it only requires courts to give weight to an agency interpretation based upon the agency's persuasiveness. Under this test, a court analyzes agency interpretations by considering "the thoroughness evident in [the agency's] consideration, the validity of its reasoning, its consistency with earlier and later pronouncements, and all those factors which give it power to persuade, if lacking power to control."166 To determine an agency's persuasiveness, courts generally look to the Congressional intent of the statute, ${ }^{167}$ consistent interpretations of the agency's authority, ${ }^{168}$ and the overall persuasiveness of the agency's reasoning, ${ }^{169}$ such as public policy

163. Melissa Hart, Skepticism and Expertise: The Supreme Court and the EEOC, 74 FORDHAM L. REV. 1937, 1942 (2006).

164. United States v. Mead Corp., 533 U.S. 218, 237 (2001).

165. See What You Should Know, supra note 145 ("Regulations issued by EEOC without explicit authority from Congress, called 'interpretive regulations,' do not create any new legal rights or obligations, and are followed by courts only to the extent they find EEOC's positions to be persuasive.").

166. Skidmore v. Swift \& Co., 323 U.S. 134, 140 (1944).

167. See EEOC v. Arabian Am. Oil Co., 499 U.S. 244, 258-59 (1991) ("Petitioners have failed to present sufficient affirmative evidence that Congress intended Title VII to apply broadly.").

168. Fed. Express Corp. v. Holowecki, 552 U.S. 389, 399 (2008) (examining the EEOC's earlier interpretations of Title VII to determine whether the interpretation at issue was consistent with the EEOC's past actions).

169. Univ. of Tex. Sw. Med. Ctr. v. Nassar, 570 U.S. 338, 361-62 (2013). 
implications.

\section{B. Applying a Skidmore Analysis}

In determining whether the issuance of a right-to-sue letter effectively limits the EEOC's investigative authority, the Fifth, Seventh, and Ninth Circuits each seemed to use elements of Skidmore. But they all failed to conduct a full analysis. Here, because the EEOC interpretation is entitled to Skidmore deference, the circuit courts should have each answered the following three questions: (1) what enforcement authority did Congress intend to grant to the EEOC under Title VII?; (2) is the EEOC' interpretation consistent with past interpretations of the EEOC's enforcement authority?; and (3) what are the public policy implications of a ruling on this issue?

Had the courts properly applied Skidmore and answered these three questions, they likely would have come to the same conclusion: the EEOC does have the authority to investigate Title VII claims after issuing a rightto-sue letter to the aggrieved employee.

\section{Title VII's Congressional Intent}

Title VII gives both explicit and implicit instructions regarding the EEOC's enforcement authority. Title VII's text provides some understanding of the EEOC's purpose. In areas where the extent of this authority becomes less clear, legislative history lends guidance to congressional intent. When the EEOC's interpretation of the statute closely mirrors the statutory language and congressional intent, courts find the interpretation to be more persuasive under the Skidmore test.

\section{a. The EEOC's Enforcement Authority under Title VII}

Title VII explicitly gives the EEOC enforcement authority. ${ }^{170}$ The limitations Title VII places upon this authority, however, are not clear. Title VII gives the EEOC's enforcement authority few temporal limits, as it only gives the EEOC a deadline by which it must grant an aggrieved party a right-to-sue letter. ${ }^{171}$ Courts have not considered this deadline a time limit upon the EEOC's investigative authority, but rather a restriction upon the aggrieved employee's right to bring a private action, as he or she

170. 42 U.S.C. $\S 2000 \mathrm{e}-5$ (2012)

171. Id. § $2000 \mathrm{e}-5(\mathrm{f})(1)$. 
must first wait out the 180-day period. ${ }^{172}$ As Petry notes, "Just as Title VII imposes no requirement that the EEOC 'conclude its conciliation efforts and bring an enforcement suit within any maximum period of time,' it also should not be read to impose an arbitrary temporal cap on the EEOC's investigatory powers." 173 Legislative history supports this interpretation. In the House report on the 1972 amendment, the Education and Labor Committee addressed the 180-day provision from the statute, stating " $[\mathrm{t}] \mathrm{he}$ primary concern must be protection of the aggrieved person's option to seek a prompt remedy in the best manner available." ${ }^{174}$ This provision alleviates that concern by allowing the aggrieved employee to regain rights over his or her own claim after a limited amount of time. What this provision does not do, however, is explicitly or implicitly require the EEOC to surrender its right to the claim after this time period has passed.

\section{b. The EEOC's InvestigativeAuthority under Title VII}

Title VII unambiguously grants the EEOC investigatory authority. As both the Seventh Circuit and the Ninth Circuit point out, Title VII not only authorizes the EEOC to conduct investigations but it also explicitly requires the EEOC to investigate once a formal charge is made. ${ }^{175}$ The statute provides: "Whenever a charge is filed by or on behalf of a person claiming to be aggrieved, or by a member of the Commission, alleging that an employer... has engaged in an unlawful employment practice, the Commission ... shall make an investigation thereof." 176

At first glance, the language of the statute may appear to place limits on this investigative authority. By explicitly asserting that the EEOC shall investigate when a charge is made, Congress might have intended for the actions of an aggrieved employee to control the EEOC's investigations and enforcement authority. Authors Shawn Twing and Travis Odom note legislative history showing Congressional intent "to limit the EEOC to investigating only those employers against whom parties have filed charges." 177 To support this argument, the authors cite to a memorandum by Senators Clark and Case, which states: "It is important to note that the

172. Occidental Life Ins. Co. v. EEOC, 432 U.S. 355, 361 (1977).

173. Petry, supra note 118 , at 1263 (quoting Occidental, 432 U.S. at 360 ).

174. H.R. REP. No. 92-238, at 2148 (1972).

175. 42 U.S.C. $\$ 2000 \mathrm{e}-5$ (b) (2012).

176. Id. (emphasis added).

177. Shawn D. Twing \& Travis Odom, Invoking Agency Jurisdiction in Employment Law Cases, 10 TeX. TECh Admin. L.J. 369, 373 (2009) (quoting EEOC v. Shell Oil Co., 466 U.S. 54, 65 (1984)). 
Commission's power to conduct an investigation can be exercised only after a specific charge has been filed in writing." 178 Twing and Odom also point out that in Hearst, the Fifth Circuit noted that "[u]nlike some other agencies, the EEOC does not possess plenary authority to demand information that it considers relevant to its area of jurisdiction. The EEOC's authority to investigate in Title VII cases is triggered only by the filing of a formal charge." ${ }^{\text {"179 }}$ This evidence of legislative intent indicates Congress wanted to tie the EEOC's authority to the actions of the employee. If the employee's charge triggers an EEOC investigation, it is not unreasonable to assume Congress intended to limit the EEOC's authority.

While this interpretation of Title VII is accurate, to conclude Congressional intent to limit the reach of the EEOC's investigative authority is also evidence of an intent to establish when the EEOC's investigative authority may end would be erroneous. Title VII only requires an employee to file a formal charge as a prerequisite to the EEOC's investigation because Congress intended the employee charge to be a triggering event for the EEOC. More likely, Congress imposed upon the EEOC the requirement that it investigate each claim filed to provide protection to aggrieved employees. The provision therefore likely does not place a limitation upon the EEOC's investigative authority, nor does the provision subject the EEOC to the actions of the employee.

There is very little in Title VII that limits the EEOC's authority. 42 U.S.C. $\S 2000 \mathrm{e}-8$ addresses the authorization the EEOC possesses to investigate discrimination claims. The section begins by providing:

In connection with any investigation of a charge filed under section 2000 e-5 of this title, the Commission or its designated representative shall at all reasonable times have access to, for the purposes of examination, and the right to copy any evidence of any person being investigated or proceeded against that relates to unlawful employment practices covered by this subchapter and is relevant to the charge under investigation. $^{180}$

The investigatory power restrictions explicit in this statute require that the information sought be "relevant to the charge under investigation."181 While this statute leaves some ambiguity as to what is considered

178. Id. (quoting EEOC v. Shell Oil Co., 466 U.S. 54, 64 (1984)).

179. Id. (quoting EEOC v. Hearst Corp., 103 F.3d 462, 464 (5th Cir. 1997)).

180. 42 U.S.C. $\$ 2000 \mathrm{e}-8$ (a) (2012).

181. Id. 
"relevant," the Supreme Court has specified that this provision is not "especially constraining" and has consistently been "generously construed" by courts. ${ }^{182}$ Therefore, the only limitation upon the EEOC's investigatory power found in Title VII is a relatively lenient rule.

Arguably, the leniency afforded to the EEOC under this provision could be limited to the scope of EEOC investigations. While the standard established by this statute could allow the EEOC a wide range in determining what is relevant to the charge, it may be more constraining if one asks how long information may be considered relevant to the charge. The language preceding the relevancy standard, however, suggests Congress did not intend to place such a temporal limit. 42 U.S.C. $§ 2000 \mathrm{e}-$ 8 explicitly allows the EEOC to "at all reasonable times have access to [relevant information] for the purposes of investigation." 183 Rather than imposing any restrictions, this provision appears to give the EEOC more latitude to determine when investigations should be done. Legislative history shows Congress intended to give the EEOC "broad powers to conduct an intensive investigation," ${ }^{184}$ providing additional evidence that Title VII gives the EEOC significant investigative authority.

Title VII is ambiguous regarding limitations upon the EEOC's enforcement and investigatory authority. Legislative history offers some insight, but in addition to statutory interpretation, a court applying Skidmore would also look for consistency in past interpretations of EEOC enforcement authority to determine whether the EEOC's Title VII interpretation is persuasive.

\section{Consistent Interpretations of the EEOC's Enforcement Authority}

Since the Civil Rights Act of 1972, the contours of the EEOC's authority have been molded both by court decisions and EEOC regulations. Analyzing the various interpretations of the EEOC's enforcement authority will shed light upon whether historical interpretations are consistent with the EEOC's current interpretation at issue here.

The EEOC has consistently interpreted Title VII as allowing it to exercise its enforcement authority outside any temporal limits. In Occidental, the Supreme Court upheld the Ninth Circuit's decision,

182. Shell Oil Co., 466 U.S. at 68-69.

183. § 2000e-8(a).

184. H.R. REP. NO. 92-238, at 2160 (1972). 
finding that the EEOC is not subject to a 180-day limitation on its authority to sue and is not governed by the state statute of limitations. ${ }^{185}$ The Court noted that Title VII only gives the EEOC one time-based limitation, which is found in 42 U.S.C. $\$ 2000 \mathrm{e}-5(\mathrm{f})(1){ }^{186}$ The Supreme Court also stated that "the EEOC does not function simply as a vehicle for conducting litigation on behalf of private parties; it is a federal administrative agency charged with the responsibility of investigating claims of employment discrimination and settling disputes." 187 Therefore, Title VII did not create the EEOC to focus only on the individual's interests when it investigates a claim.

The Supreme Court's interpretation that the EEOC is not a litigation "vehicle"188 is consistent with the way the EEOC interpreted its power in 29 C.F.R. § 1601.28(a)(3). Similar to 29 C.F.R. § 1601.28(a)(3), Occidental gives the EEOC the ability to exercise its enforcement authority outside of regulated temporal limits. Further, the Court's holding in Occidental establishes that the EEOC's enforcement power is not subject to the same limits upon an individual's ability to sue, such as a statute of limitations. This suggests the Court interprets Title VII to allow the EEOC to operate separately from the aggrieved individual.

The notion that the EEOC is a vehicle for enforcement separate from the individual is echoed in General Telephone Co. v. EEOC. ${ }^{189}$ In General Telephone Co., the Supreme Court addressed whether Rule 23 of the Federal Rules of Civil Procedure prevents the EEOC from seeking classwide relief for a discrimination claim. ${ }^{190}$ While the Court analyzed the plain meaning of 42 U.S.C. $\S 2000 \mathrm{e}-5(\mathrm{f})(1)$, it also assessed the purpose of Title VII, finding that a Rule 23 limitation would frustrate the purpose of the EEOC's enforcement power. ${ }^{191}$

The Court stated that it is within the "clear purpose" of 42 U.S.C. $\S$ 2000e-5(f)(1) to give the EEOC "authority to bring suit in its own name for the purpose, among others, of securing relief for a group of aggrieved individuals." ${ }^{\prime 192}$ The Court noted that the 1972 Title VII amendments

\footnotetext{
185. Occidental Life Ins. v. EEOC, 432 U.S. 355, 358 (1977).

186. Id. at 360. See also supra Section III.B.1 (discussing Congress's intent for the limits of the EEOC's authority in Title VII).

187. Occidental, 432 U.S. at 368.

188. Id.

189. 446 U.S. 318,326 (1980).

190. Id. at 320 .

191. Id. at 323-25.

192. Id. at 324 .
} 
allow for an individual employee to bring a private action separate of the EEOC. ${ }^{193}$ This provision seemed to "suggest that the EEOC is not merely a proxy for the victims of discrimination and that the EEOC's enforcement suits should not be considered representative actions subject to Rule 23." 194

General Telephone Co. asserts that the EEOC is expected to bring suits as part of its duty to eradicate discrimination in the workplace. ${ }^{195} 29$ C.F.R. $§ 1601.28(a)(3)$ allows the EEOC to bring suits to accomplish this goal, while also allowing individuals to bring separate actions.

Finally, in EEOC v. Waffle House, ${ }^{196}$ the Supreme Court analyzed whether the EEOC may continue to seek victim-specific compensation once the aggrieved employee has signed an arbitration agreement with the employer. ${ }^{197}$ The Court found the EEOC was not limited by the actions of the employee and that 42 U.S.C. $\$ 2000 \mathrm{e}-5(\mathrm{f})(1)$ unambiguously made the EEOC the "master of its own case." 198 The Court pointed out that Title VII clearly gives the EEOC command over the employee's claim because of the authority Title VII expressly grants to the agency. ${ }^{199}$ Title VII gives the EEOC the right to exercise exclusive jurisdiction over the employee's claim for 180 days, to issue a right-to-sue letter to the employee, and to file suit in its own name. ${ }^{200}$ From Title VII, the Court concluded the EEOC may determine how and when to bring a judicial claim, and to hold otherwise would be an abuse of the court's power. ${ }^{201}$

In accordance with the idea that the EEOC is the "master of its own case," its interpretation of Title VII in 29 C.F.R. $\S 1601.28(a)(3)$ gives it the authority to decide when it will enforce the case. ${ }^{202}$ Even after issuing a right-to-sue letter, the regulation allows the EEOC to continue to investigate the charge if it "determines at that time or at a later time that it would effectuate the purpose of Title VII ... to further process the

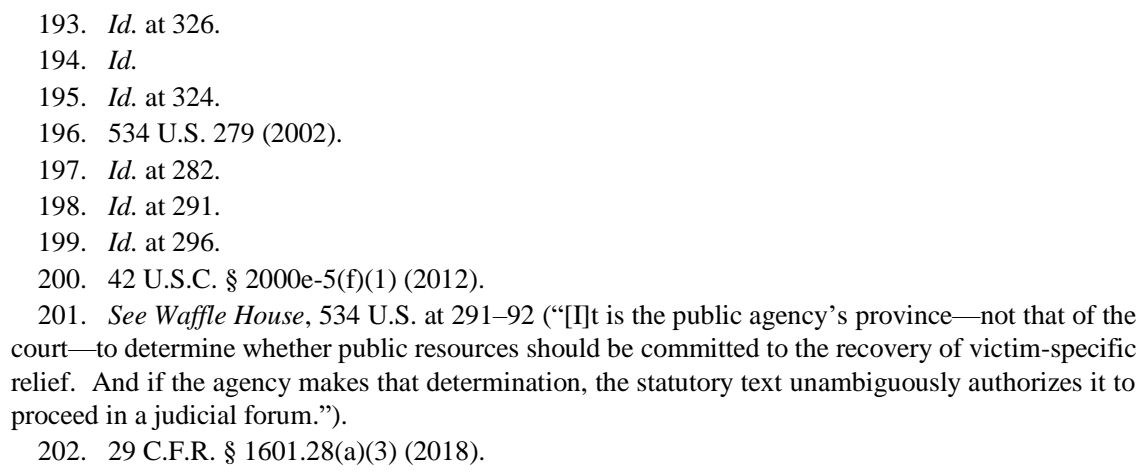


charge. $" 203$

From these cases, a clear pattern of interpretation emerges. The EEOC has consistently interpreted its authority as allowing it to exercise enforcement separately from the individual employee. This interpretation has been upheld by the Supreme Court, which found support in Title VII and public policy. The EEOC's interpretation that it may investigate claims after issuing a right-to-sue is not a far cry from the interpretations made in Occidental, General Telephone Co., and Waffle House. The EEOC's regulation here is thus a consistent interpretation of its enforcement power under Title VII.

\section{Public Policy Implications}

Perhaps the most controversial aspect of this issue is whether allowing the EEOC to investigate after issuing a right-to-sue letter would have positive or negative public policy implications. Those who evaluate the policy issues are left weighing the interests of employees, employers, and the public. While the Fifth, Ninth, and Seventh Circuits touched briefly upon this issue, they only mentioned a few of the implications upon the employer and the employee and failed to truly dive into the public policy implications. ${ }^{204}$

While it should not be used as the sole method to determine whether an agency interpretation is valid, assessing the public policy implications can be a tool for evaluating the persuasiveness of an agency interpretation under Skidmore. ${ }^{205}$ While advocates on both sides of the controversy raise important points, limiting the EEOC's investigative authority will result in far more troubling consequences, lending a more persuasive argument in favor of the EEOC's interpretation. The public policy implications include protecting the public interest, protecting the employee's interest, protecting the employer's interests, and checking the EEOC's agency power.

203. Id.

204. See supra Section II.C.

205. Skidmore v. Swift \& Co., 323 U.S. 134, 140 (1944) ("The weight of [a judgment of an administrative regulation] in a particular case will depend upon the thoroughness evident in its consideration, the validity of its reasoning, its consistency with earlier and later pronouncements, and all those factors which give it power to persuade, if lacking power to control."). 
a. Protecting the Public Interest

One reason the Fifth Circuit's decision in Hearst was flawed is because it erroneously assumed the EEOC and the employee acted as one party in conducting the four stages of Title VII enforcement. The Fifth Circuit held that the fourth stage of enforcement begins once the employee initiates litigation, thus moving the EEOC out of the investigation stage. ${ }^{206}$ However, as the Ninth Circuit pointed out in Federal Express, the Fifth Circuit in Hearst does not explain why the enforcement stage must bring an end to the EEOC's investigation. ${ }^{207}$ Hearst provides a scheme that is contrary to the purpose of the EEOC.

Legislative history tells us the EEOC was created by Congress to put a stop to workplace discrimination by enforcing "pattern or practice suits." ${ }^{208}$ This emphasizes that the purpose of the EEOC's enforcement authority is for more than simply litigating on behalf of private individuals. $^{209}$ When the EEOC investigates, it does so with the public interest in mind, and it enforces Title VII to protect the public from the harmful consequences of an employer's discriminatory conduct. The EEOC should therefore not be controlled by the actions of an individual employee, who only acts on her own behalf.

If courts determined the EEOC's investigations must end after an aggrieved employee receives a right-to-sue letter, it is not difficult to imagine various scenarios that would be contrary to the public's interest in preventing workplace discrimination. For example, many employees who file complaints with the EEOC face threats to their employment. Because they are confronting the possibility of losing their paychecks, aggrieved employees do not always think they have time to wait for the EEOC to conduct a thorough investigation of an employer's pattern of discrimination. Conversely, the public has an interest in seeking out and stopping those employers who systematically discriminate in the workplace, a feat that the EEOC is usually more equipped to handle than an individual employee. The EEOC can achieve greater results by suing on behalf of an entire workforce than an individual employee seeking damages for herself. Low settlement payments to an individual employee is hardly a deterrent to a discriminating employer. If an employee's own suit ends the EEOC's claim, the employer is more likely to continue his

206. EEOC v. Hearst Corp., 103 F.3d 462, 469-70 (5th Cir. 1997).

207. EEOC v. Fed. Express Corp., 558 F.3d 842, 851-52 (9th Cir. 2009).

208. H.R. REP. NO. 92-238, at 2149 (1972).

209. Occidental Life Ins. v. EEOC, 432 U.S. 355, 368 (1977). 
pattern of discrimination against other employees.

Title VII assumes an administrative agency has greater resources and influence than an individual to root out pervasive discrimination practices in the workplace. Because of the high number of charges that are filed with the EEOC on a regular basis, ${ }^{210}$ it may not always be practical for the EEOC to wait the full 180 days on every charge filed with the agency before it can give employees the right to bring their own claims. Without the ability to simultaneously discharge a right-to-sue letter to the individual employee while continuing to investigate an employer's pattern of discrimination, the EEOC is forced to decide between protecting the individual and protecting the public. This is contrary to the EEOC's purpose under Title VII, as it would not allow the EEOC to enforce both pattern and practice suits to eradicate widespread discrimination practices.

\section{b. Protecting the Employee's Interests}

The dilemma above also has the possibility of harming the employee. The 1972 amendments to Title VII were not supposed to replace an employee's private right of action with EEOC suits. ${ }^{211}$ In fact, legislative history shows that Congress specifically did not want to undermine the employee's ability to seek judicial relief. ${ }^{212}$

Title VII creates an expectation that the EEOC will first use conciliation before resorting to litigation. ${ }^{213}$ Therefore, the EEOC's primary interest is reaching a peaceable solution outside the courtroom. This interest, however, may not be shared by the employee. If the EEOC's authority is terminated by the issuance of a right-to-sue letter, it may be reluctant to issue the letter to an aggrieved employee. However, if workplace discrimination caused the employee harm, it is easy to believe

210. In January of 2018, the EEOC released its enforcement data, showing that the EEOC received 84,254 workplace discrimination charges in the 2017 fiscal year. Press Release, U.S. Equal Emp. Opportunity Comm'n, EEOC Releases Fiscal Year 2017 Enforcement and Litigation Data (Jan. 25, 2018), https://www.eeoc.gov/eeoc/newsroom/release/1-25-18.cfm) [https://perma.cc/7NM8-F3TS] [hereinafter EEOC Press Release].

211. See EEOC v. Goodyear Aerospace Corp., 813 F.2d 1539, 1542 (9th Cir. 1987) ("Its interests in determining the legality of specific conduct and in deterring future violations are distinct from the employee's interest in a personal remedy.").

212. H.R. REP. NO. 92-238, at 2148 (1972) ("The primary concern must be protection of the aggrieved person's option to seek a prompt remedy in the best manner available.").

213. 42 U.S.C. § 2000e-5(f)(1) (2012); see also Elizabeth Dunn, Comment, No Longer a Paper Tiger: The EEOC and Its Statutory Duty to Conciliate, 63 EMORY L. J. 455, 473 (2013) (arguing that "Title VII imposes a framework that encourages conciliation in lieu of litigation"). 
she may have an interest in pursuing litigation. ${ }^{214}$

Further, a limitation upon the EEOC's ability to investigate claims would create an unfair loophole for employers. If the EEOC could no longer investigate after an employee receives a right-to-sue letter, employers might be incentivized to settle with the employee for a relatively small amount, knowing the employee has little bargaining power. The employer could then continue its discriminatory practices in the workplace without fear of enforcement from the EEOC and the employee would not receive the damages he or she could have been entitled to in a court of law. ${ }^{215}$

\section{c. Protecting the Employer's Interests}

Some argue that a temporal limit upon the EEOC's investigative power is necessary to protect employers. In his dissenting opinion in Waffle House, Justice Thomas expressed concern that a refusal to limit the EEOC's enforcement power would allow an employee "two bites at the apple" 216 _ one bite from his or her private litigation and one bite from EEOC enforced litigation. ${ }^{217}$ Although this is a concern, there are ways to minimize the unfair effects of getting "two bites at the apple." 218 If the employee wins both the individual claim and the EEOC claim, the court can restrict the damages award. In fact, as the majority points out in Waffle House, the courts are already expected to limit damages to prevent double recovery. ${ }^{219}$ The EEOC will therefore not be awarded victim-specific relief if the victim has already received damages.

Despite the limits upon damages, allowing the EEOC to continue litigation after issuing a right-to-sue letter could still cause the employer

214. This hypothetical situation is similar to a situation faced by a plaintiff in an Indiana District Court case. The plaintiff, Sheryl Parker, filed a claim with the EEOC, claiming her employer violated Title VII. On the same day Parker requested a right-to-sue, the EEOC invited Parker's employer to participate in a settlement discussion. Regardless, the EEOC issued Parker the right-to-sue letter. See Parker v. Noble Roman's, Inc., No. IP-96-65-C-D/F, 1996 WL 453572, at*1 (S.D. Ind. June 26, 1996).

215. EEOC investigations can be incredibly costly and time consuming for employers. If the case goes to trial, employers could face paying the employee lost wages, legal fees, and damage awards. The financial penalties for a finding of a pattern of discrimination could be even higher. See EEOC Complaints: Everything You Need to Know, UPCOUNSEL, https://www.upcounsel.com/eeoc-complaints [https://perma.cc/2K3NPHTQ] (last visited Oct. 24, 2019) [hereinafter Everything You Need to Know].

216. EEOC v. Waffle House, Inc., 534 U.S. 279, 310 (2002) (Thomas, J., dissenting).

217. Id.

218. Id.

219. Id. at 297. 
to take a double-hit. EEOC investigations are costly and timeconsuming, ${ }^{220}$ and public litigation could cause severe damage to an employer's reputation. ${ }^{221}$ But it is important to note the likelihood that the EEOC would continue to investigate a claim after the employee has already been issued a right-to-sue letter is very low. ${ }^{222}$

Further, Title VII does contain some provisions to ensure fairness to the employer and to offer protection from frivolous claims. Under the statute, the EEOC is able to bring litigation only after it has determined: (1) there is reasonable cause, and (2) attempts to achieve a peaceable settlement have failed. ${ }^{223}$ When evaluating reasonable cause, if the employee has already received judgment from her own civil action, such as in Union Pacific, ${ }^{224}$ the EEOC will probably consider the employee's civil action judgment. If the EEOC still finds there is reasonable cause to believe there is discrimination, the employer has the chance to avoid litigation by participating with the EEOC in settlement and conciliation methods. While these methods can also be expensive and time-consuming for the employer, it is far better than a civil trial.

Finally, the EEOC's inability to continue enforcement after issuing a right-to-sue letter could negatively affect conciliation efforts. Imagine a situation in which the EEOC feels it is in the best interest of the public to retain control over a claim and therefore rejects an employee's right-tosue letter before the expiration of 180 days. After conducting a thorough investigation, the EEOC decides to begin conciliation efforts between the employee and the employer. Even if the employer is eager to reach a fair settlement, the aggrieved employee could be less willing to compromise. For this reason, the EEOC and the employer's conciliation efforts could be undermined by an aggrieved employee who desires more compensation

220. See What You Can Expect After a Charge is Filed, supra note 39 (explaining the information seeking process and the average time it takes to complete an investigation and resolve a charge being 10 months); Everything You Need to Know, supra note 215.

221. John R. Allison, Five Ways to Keep Disputes Out of Court, HARv. Bus. Rev., https://hbr.org/199 0/01/five-ways-to-keep-disputes-out-of-court [https://perma.cc/CSN3-QBGV] (last visited Oct. 24, 2019) ("Although judges can issue protective orders covering legally qualified trade secrets, much valuable proprietary information cannot be protected in a trial. Moreover, any hearing in a public forum can lead to embarrassing revelations of business and personal behavior, with predictable and not-so-predictable adverse effects on customers, suppliers, shareholders, employees, news media, and even legislative and regulatory bodies.").

222. See infra Section III.B.3.d; see also Petry, supra note 118, at 1267 (finding that while the EEOC's attempt to continue an investigation after issuing a right-to-sue letter "appears to have emerged infrequently ... that could simply reflect a lack of reporting or a lack of appeals").

223. 42 U.S.C. $\$ 2000 \mathrm{e}-5$ (b) (2012).

224. EEOC v. Union Pac. R.R., 867 F.3d 843, 851 (7th Cir. 2017). See also supra text accompanying notes 104-10. 
for her claim. Interferences with the EEOC's conciliation authority is in direct conflict with Title VII's intentions. ${ }^{225}$

\section{d. Checking Agency Power}

Critics of the broadly conferred investigative power also worry that investigations would have the potential to continue longer than necessary if they are not limited. Employers should not have to live in fear of facing constant EEOC investigations, nor should the EEOC be able to operate freely without checks upon its power. However, the fear of constant EEOC investigations in the workplace is not necessarily realistic. ${ }^{226}$ Although 29 C.F.R. $\S 1601.28$ (a)(3) gives the EEOC the authority to decide when it will enforce a case, the EEOC is still subject to limitations on its enforcement power. From a practical perspective, the EEOC works with a limited budget and an increasingly large caseload. ${ }^{227}$ There simply is not enough time or money for the EEOC to spend months investigating every claim they receive. The EEOC also operates under the watchful and political eye of taxpayers. It would be impracticable for the EEOC to keep investigations pending indefinitely, or to conduct "fishing expeditions" on employers. It is usual practice for the EEOC to terminate investigations after issuing a right-to-sue letter. ${ }^{228}$ In fact, 29 C.F.R. $§ 1601.28(a)(3)$ states that, once an employee receives a right-to-sue letter, the EEOC will stop the investigation, unless it determines that the investigation should remain open to "effectuate the purpose of Title VII." 229 While, as this Comment argues, this provision does not put temporal limits upon the EEOC, it does direct the EEOC to only continue investigations when there is compelling evidence of workplace discrimination. Therefore, the EEOC would rarely find reason to continue its investigations after it issues a right-to-sue letter.

Despite this issue's rarity, it is in the public's best interest that the

225. See 42 U.S.C. $\$ 2000 \mathrm{e}-5(\mathrm{f})(1)$ (2012).

226. Petry, supra note 118 , at 1262 .

227. In January 2018, the EEOC released its enforcement data, showing that the EEOC received 84,254 workplace discrimination charges in the 2017 fiscal year. EEOC Press Release, supra note 210; see also Charge Statistics (Charges Filed with EEOC) FY 1997 Through FY 2017, U.S. EQUAL EMP. OPPORTUNITY CoMM'N, https://www.eeoc.gov/eeoc/statistics/enforcement/charges.cfm [https://perma.cc/ZUN8-J5UG] (last visited Oct. 24, 2019) (listing the thousands of charges filed each year with the EEOC); Casey Quinlan, This Bill Won't Let Employers Force People to Sign Non-Disclosure Agreements Related to Harassment, THINKPROGRess (June 6, 2018, 12:54 PM), https://thinkprogress.org/bill-prohibits-non-disclosureagreements-harassment-workplace-f469f50eb132/ [https://perma.cc/6RJT-4PK5] (noting that the EEOC is not well-funded).

228. Petry, supra note 118, at 1227.

229. 29 C.F.R. $\S 1601.28(a)(3)$ (2018). 
EEOC retain the authority to continue investigations after issuing a rightto-sue letter. To hold otherwise would create harmful effects for victims of workplace discrimination and perpetuate discriminatory practices.

\section{CONCLUSION}

Since the creation of the EEOC, courts have debated the extent of the Commission's enforcement and investigative powers under Title VII. The lack of guidance on how courts should analyze the EEOC's Title VII interpretations led to a circuit split among the Fifth, Seventh, and Ninth Circuits. The circuit courts failed to address the issue of deference, but determining which level of deference, if any, the EEOC's interpretation of Title VII is entitled to should have been the starting point. This Comment argues the EEOC's interpretation of Title VII is entitled to Skidmore deference. Once courts know the level of deference to give the EEOC, they can then go on to ask whether the EEOC's interpretation of its investigative authority is a persuasive interpretation of Title VII, and thus, an appropriate exercise of its enforcement authority.

Under Skidmore, a persuasive interpretation of Title VII has statutory authority, past interpretations that are consistent with the one at issue, and public policy reasons supporting it. After analyzing these three elements, it would be proper to conclude that the EEOC's investigatory authority is not limited to the actions of the aggrieved employee. Thus, 29 C.F.R. $\S$ 1601.28(a)(3) is a valid interpretation of Title VII. The Supreme Court and Title VII give the EEOC broad authority to investigate and enforce discrimination claims. Limiting this authority would undermine the EEOC's purpose. Title VII's mandate that an employee must file a formal charge before the EEOC may investigate is only indicative of when Congress intended the investigatory stage to begin, and not to dictate when it must end. Legislative history lends its support to this conclusion. Furthermore, there are serious public policy implications that would arise if the EEOC's power is limited by the employee's litigation.

The EEOC's investigative power is only one facet of the agency's relatively broad authority to eliminate widespread workplace discrimination. As courts determine whether this authority should be limited, they must take care to analyze each aspect of the agency's authority. Perhaps most importantly, the courts should remember the implications EEOC limitations will have upon the federal government's ability to regulate harmful workplace practices. 